\title{
Challenging the Future with Education
}

\author{
Kuncoro Asih Nugroho \\ State University of Yogyakarta
}

\section{ABSTRACT}

The paper discusses the possible ways' of improving the quality of education 'in Indonesia in the future. It starts with the background describing the reality of the education - now adays and the need of making changing in any aspect of education.

To yield better products of education, there must be improvements in the process of education, in which each components of education system should interact one another. Besides, the purpose of education should be clear and inclusive which does not only concern in' the cognitive side but also in affective and psychomotor sides. After setting the purpose 'of education, there must be a change in education páradigm as well. We have to see that education is a means to make students mature in their life. To generate change, innovations must be made by any parties of education process. Especially teachers should always innovate their teaching method so that the result of their teaching process will be maximum. Last but not least, education should ensure the output and the outcome. When the aspects above mentioned are well carried out, education will not only yield better output, which has good grades or marks, but it will also yield better outcome, which will not find difficulties in getting the first job.

Key Words: future, education

\section{A. Introduction}

The development of the world requires us to have the ability to solve problems, which have to be flexible since everything' always changes in the world. Better chan'ges are what everybody expects. People are always expected to have thorough ability to improve the quality of their life. What we mean by thorough ability here' is both physical and psychological ones. That ability can also be seen from such aspects as cognitive, affective, and psychomotor aspects.

The way to optimize those abilities can be carried out by education. In other words, education has to enhance the students" both physical and psychological' abilities. Eduication process should not only put the emphasis on cognitive aspects but it has to consider the affective and psychomotor aspects: If all the three aspects are improved, education will not onty yield smart people but also will result in good generation with qualified skills and noble morality. We cannot taste the fruits of the education process in a short time but it needs long time since education process takes a long time.

Although people know exactly the benefits of education, not all people give good education for their children. The have-nots and people from remote area prefer meeting their immediate needs (to satisfy on-going will). They are not aware yet that education will change their life in to a better one. People cando more if they have the knowledge and skills. 
There is a tendency that it is the parents who want their children go to school while the children themselves'are reluctant. To motivate their children, then, parents grant whatever the children want. If education has been put as the most prominent thing, people will go to school despite budget constrain. And parents are usually reluctant to send their children to school if they have worked.

Education practitioners have been counting on education to face problems in the future. Education is future investment which means that education will determine whether a country will develop or not. Considering this fact, the government of Indonesia starts rising the budget for education up to $20 \%$ of the Total National Income and Cost (APBN). With the $20 \%$ the government hopes that it can improve the quality of education so as to yield better product. The governmentalso improves the facilities and the teacher's welfare.

Innovations have been made to face the rapid grow of the world. Innovations include ones in the class, which include both the hardware and software (the teacher's skills).

We cannot see the product or education in a short period. Take for example; a student has to take 15 or 20 years of school to finish from elementary to high school or university. Hence, we can see the result of educating a certain generation in 20 years.

Even though we have waited for twenty years, we cannot guarantee that the result will be satisfying, however. An education process can be said to be good if it can produce graduates which fit the need of the market or the society. An education process can be said successful if it can make the students able to fulfill their needs after graduation. If it is not successfiul, however, it will only produce unemployed individuals, or it will produce smart people without heart because it does not care about such aspects as cognitive, affective, and psychomotor all together.

\section{B. The Process of Education}

'1. Education as a system

1.. . Education is a conscious process to humanize people. Education process aims at improving intelligence, behavioral' skills, attitude and personality for the future. Education process is carried out through counseling, training and educating.

According to law No. 20.2003, education is a conscious education is a planned and conscious process to create learning environment and learning process so that the students actively improve their potencies to have spiritual and religious power, self control, self identity, smartness, noble attitude, and skills needed by themselves, the society, the state and the nation.

There are some components involved in the process of education, where there are synergic interactions among components to reach the end. The components can be smaller systems. And the interactions are not only among components within the system but also between those in and outside the systems.

The components outside the education system are among others: students' parents, the low level government, custom of the society, facilities outside the school, and factories around the school. A school as the wheel of the education process has to be able to interact with the environment. Schools can involve the parents and the low level government in the policy making; the factories around the school can be invited to help the fund in the form of scholarships or other funding system; and the facilities outside the school can be used to support the process both as the teaching media and other supporting functions.

Slamet PH (2000: 321-327) states that life is a system which universally inciudes such components as input, process and output The definition of the components is as follows:

- The component called imput is everything which has to exist and is needed for the process to run. The input does not have to be things but it can be tools and hopes as the guide for the guarantee that the process nuns. Input generally includes vision, mission, objectives, target, the input of management and human resource. 
- The component of system called process is the changing of a certain state to another state. In the micro-scale education or is a school, the process includes the process of decision making, the management of institution, program management, staff motivation, coordination, teachinglearning process, monitoring process and evaluation.

- The component of system called output is anything resulted from the process. The output resulted from the process should be ensured and guaranteed so that the effectiveness can be recognized. The effectiveness is a measurement stating how far the objectives (quality, quantity and time) or the real outcome is divided by the expected result If each component does not work properly, or if the interaction among components, the objective of the system cannot be well reached. In education system, teachers are the front liners so that the quality of teachers has to be good. Besides, the interaction among academia has to be perfect as well. The communication among teachers, students, staffs, and the headmaster has to be guaranteed that it will support the process of education. If those components have poor communication, the process will be paralyzed.

Management is badly needed in education process to run the process smoothly. Each component can work synergetically if there is one who manages them. Whether the result will be good or not, it does depend on the management'of the process. Good input does not guarantee optimum output if the process is not well nm.

Decisions made in education process should pay full attention to output and outcome. The decision to recruit the students while they are taking the education and hire directly after graduation by the government should only be taken for an emergency; to meet the need of a remote area, for example. While in normal condition, it should not be done since it will decrease the quality of the graduates. Theirtarget is only to pass the test not to learn the skills taught in the education.

Hence, the government should reconsider the system of recruiting students while they are still at school. If the government still wants to do it, standard criteria must be used to maintain the quality of the graduates so that their target is not only passing the exam but also improve their quality. The offer of working in a certain place should be conditional. If they cannot show their quality in the graduation, they will not get the job.

Department of National Education (2002:1) state that factors affecting the uneven quality of education are among others: the policy and the running of education use education function approach or input-output analysis which isnot done in the right order.

The process of education is carried out in central bureaucracy that places a school as the agent of education process dependent too strongly on the central govemment policy. And the process of decision-taking takes too long course and even more the decision sometimes is not inline with the condition and nature of the school. It does not suit the unique condition of the school and unfortunately the role of the society especially the parents of the students are not maximizedyet.

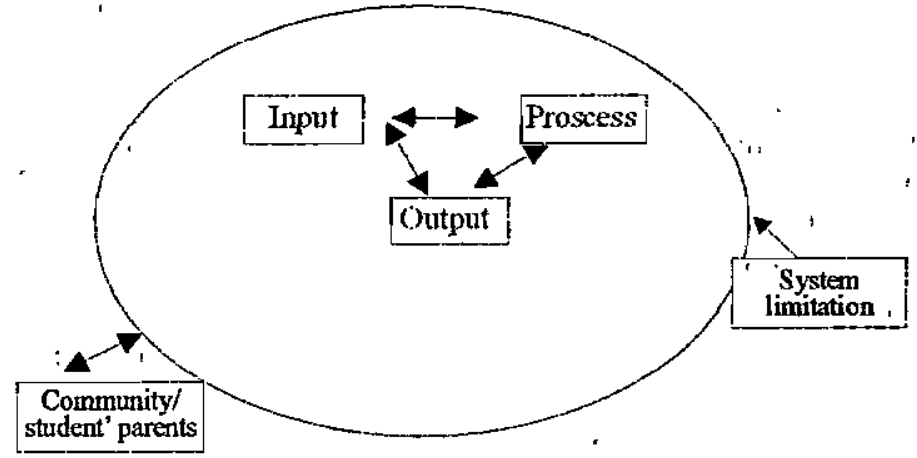


According to Knight (1982:9) education and training are specialized types of learning while training, in turn, is a specialized type of education. Schooling is related to the three form of learning in these sense that inadvertent learning, education, and training may take place in the context schooling.

Figure 2: The relationship of selected learning - related Concept

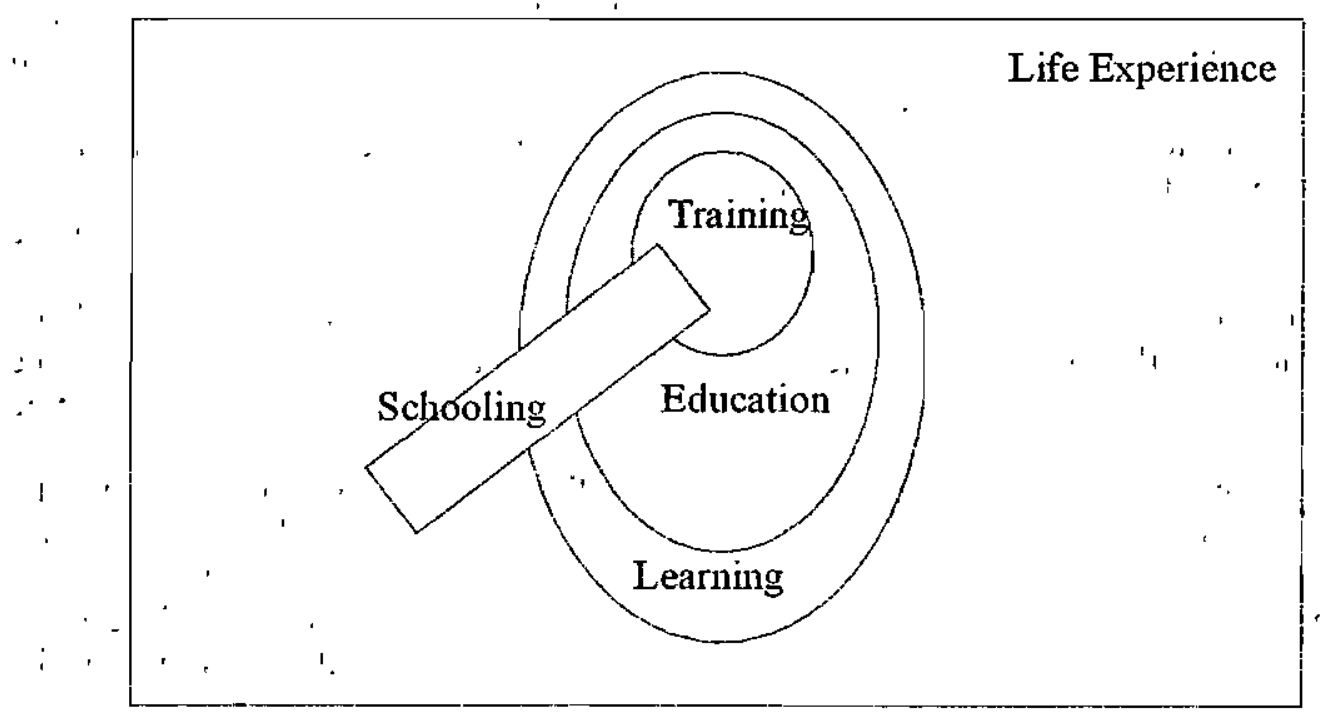

Learning should not finish after graduation form the school but it should be long life. Why should it be? The answer is because the longer people live in the world the more life experience they encounter. The experience of facing problems in life requires people to continuously learn: We will surely get behind if we stop studying or learning.

Long life learning should also be done by educators since they have to transfer their knowledge. If they don't teach in line with the development of the world, the students will get behind too. The knowledge they get will not suit their era. Therefore they cannot use their knowledge to challenge the world so that they can survive living their life.

\section{The Purpose of Education Process}

Education as a system has a purpose, which according to Hasbullah (6:12-13) is as the course of education which becomes the termination of education and the onset to achieve other goals, and to value other attempts.

An education institution should have vision and missions which will become the goal to be achieved in either long or short period of time. The vision and mission of an education institution should be set to satisfy the development of the world. If the first mission is successfully pulled off, the result can be used to determine whether the short term goal can be accomplished or not. Hence, we can use the result of the previous achievement to resolve the next mission which will lead to the vision.

Based on the law of Republic of Indonesia Number 20 year 2003 on National Education System regulation 3, education functions as toois to develop skills, character and national dignity in the aim of smartening up the nation, developing the students potencies so as to become individuals 
Who are faithful and believe in the God; who possess morals and noble character; who are healthy, knowledgeable, competent, creative; independent; and as citizens, are democratic and reśsonsible.

$\because \quad r$ The vision and mission set by an education institution should be based on the'goal iof national 'education. Each institution may highlight specific goal; but should be in line with the goal of national education.

$\therefore$ - Good goals set by the institution and the success of achieving it can influence the quality of the graduates. The goals with future orientation will lead the graduates to the work with no constraints. We can assume that the graduates are goods and the users are customers. In' the businèss world, customers will search for goods suited with their needs. An education institution thén has to prepare the students with knowledge and skills suited with the needs of the future customers. 'Graduates having skills which are not in line with the need of the market 'will get difficulties in finding a job and will worse the unemployment. The condition and quality of the graduates in the future are strongly determined by the decisions on education today since it takes along' time to harvest graduates.

$\therefore \quad$ 'In fact, on the other hand, there are a lot of graduates with high GPA but they find difficulties in getting a job. The graduate users do not only count on the grades but they also have views regarding the future need or we can say with future-oriented. The goals of a certain education institution, then, have to maniage to answer the demands.

\section{The Change of Education Paradigm}

Conventional education is generally teacher-centered, which means that teacher is the only source of knowledge. Since teacher is very dominant, students' experience and prior knowledge is not considered at all. As a result, students' critical thinking does not get trained and improved. :

Education process should make the students active in participating in the class activities. They should not be considered as blank paper, who knows nothing. They have prior experiences that teachers, as facilitators, should explore in the teaching.learning process. By dóing this, teachers will have developed the students' critical thinking since they get used to observing realities. Learning process involving real condition will stimulate the students to be aw education paradigm:

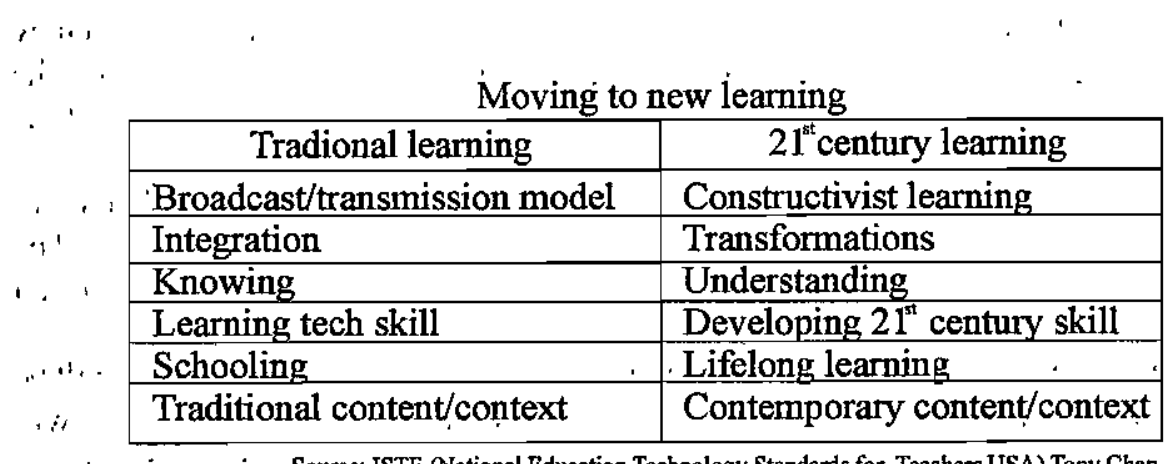

Source: ISTE (National Education Technology Standards for Teachers USA) Tony Chen.. Quoted from the $43^{\text {rd }}$ amniversary speech of Suyanto (2007:16) 


\section{Innovationsin Learning}

Schools are the lowest education institution in the hierarchy of formal education organization. It is the place where teachers and students meet and interact. During the interaction, which is in class, the process of leaming occurs. Hence, the process of transferring knowledge and values of life happens in the class. Although most of learning activities happen in the class, it is not impossible that it will happen outside (out door activities). And the learning activity carried out by teachers and students will support the achievement. of education goals since the teaching learning process is the core of education activity in achieving the result of the education process.

The learning process needs good input and management so as to yield optimal learning result. In terms of input, there are two sources, human and non human. Human input can be from the students, teachers, administration staff's and other staffs, while non human input can include teaching media, evaluation tools, manufacture and infrastructure, and the environment.

Since the activities happened in the class is the mainstay of education process the innovation in doing it should be taken into consideration. It is a must to innovate in the classroom since monotonous way of teaching is boring for the students. When they are boring they will not participate fully in the class and as a result, the gain is not maximal. Creative teachers, on the other hand, will always make imnovations in the class so that the class will not be boring. They will try to get the students' full participation by making something different so that there will always be something new in the class.

What is meant by innovation here is not always making something new; it can be in the form of developing or improving the existing methods. It cam be done in the teaching method, teaching media, and in the materials being taught. Basically it iscarried out for the sake of better and optimum result:

Innovation in the classroom can be donein the model, method, and stident organization or grouping. Some ways nayy also be used, which are reword and pumishmenté, motivating the students and advancing the materials. Classroom research will help much in making innovations in education. The research gives more emphäsis ôn the learning prócess. Thè weaknesses and success of the leaming process' are mónitored in that teacher has to improve when there are unsuccessful method. It is expected that the teacher will get much better method of teaching the clàss. It does not only take a short time, though.

The teaching method should match the materials being taught, the subject, and the facilities available. Take an example: teaching methods called discovery and inquiry is suitably used in teaching science. Whatever method is applied, it should make the studenits more active. Problem-based learning is one of the examples. Students are given a certain problem and they have to solve it in the class. They may be grouped and have to discuss the problem and the teachers provide the facilities to solve 'the 'problem: "The" product of the group work is conclusions. After finishing the discuission, the group should jicsent it to the class. There are possibilities that they will not have the same results. This is the chance that the students will argue and try to broaden their knowledge so that they will end up in the right conclusion. The role of the teacher is to give reinforcement if the conclusion made is correct and give correction ifit is not.

Working in groups, students will develop their individual and social skills. They will be able to develop their cognitive, affective and psychomotor'skills simultaneously. They will develop themselves by leaming to solve the problems. In doing so, each student can propose their ideas with the arguments of comse. The social skill will develop indirectly by the process of appreciating, listening, and accepting other ideas. 
Teacher can make the students more proud of the result of their discussions if it is not only presented and graded They will be more satisfied when it can be published and even more be used by others. Teacher can have their works exhibited on a wall or an exhibition conducted by the school. Such activities will improve the students' brevity and creativity and encourage the students to develop their writing habit.

When the problem is complicated and needs a long time to solve, it can be done in a project-based activity. The idea of finishing the project is the same as that in problem based: It is divided into smaller projects and finished in a semester time with certain goals in each smaller project.

Being innovative for teachers can be in the development of the materials. Since the materials are developing in line with the development of the'world, it is a must for teachers to update the knowledge to catch up with it. There are some sources teachers can access' to cope with the problem, internet, journais, magazines', research results, books and encyclopedia. Teachers can have new insight by taking some courses, seminars and trainings as well. By döing so, teachers will not get behind in terms of the development' of the knowledge and the application. To be able to get better access, teachers should be technology literate so that they can use the internet to up date new information and knowledge.

Teachers can work together with universities as information developer in bettering their teaching methods and material up dating. They can propose trainings to universities; they can also carry out a joint research between teachers and lecturers of a certain university. It will give benefits to the teachers in terms of problem solving.

Teaching media used in class should be varied to match the demand of the growing materials. The more the students are exposed to direct reality, the easier they learn and the broader their vision is. Realia or real environment is very effective since it is close to the nature. It helps a lot since students usually find it difficult to understand and read the omens the nature has. "Using the nature as a media will also lessen the boredom since they have wider view. compared to the view they have in the class.

The media teachers use in the class should also be various since the application of concepts in our life is not limited to one aspect. The function of teaching media is to show those aspects. Teachers need to have creativity, knowledge and experience to develop such media. If there is limitation in terms of the number, media can be given in groups and then each groúp demonstrate the knowledge the get from the media.

Despite the importance of the media in the learning process, teachers are sometimes reluctant to make them since they are 'quite busy. Yet, teachers actually can assign students to produce the media to be used. They will develop their creativity skill when developing the media. They will be proud when the mediais used in the class and as a result the learning próces's will be more interesting. It is not impossible that the students will make more creative media so that the teacher will also learn. With the fact that the teacher learns from the students will inake thém 'proud and motivatèd. For teachers, the students' creations will enrich their teaching media in terms of the type if they are new.

The development of information technology can be used as teaching media. Using IT, teachers can employ e-learning so that the students do not find difficulties in accessing resources the teachers'sassign. A's a result, 'students will be active learners: It is expected that the students will gain more than the teachers can give.

Despite the success of e-learning, we need to be aware of 'certain things ' when employinge-learning. Wehave to consider the affective aspects of the students. It is hard for the teacher to know whether the students are honest or not when doing the assignment through ' 
e-learning. When the type of the items is essay, the teachers will still be able to determine whether the students do the assignment by himself or not. On the other hand, it will be difficult when it is multiple choices.

Innovation in education materials is highly possible to improve especially for a teacher. This is so, since the curriculum in an education unit gives chances for the teachers to develop the learning materials. It is quite reasonable that the condition of the input is different from school to school. A school with highly qualified input of course will deepen the materials more than the other schools. The, quality of the teachers, then, is highly recommended in designing the materials. Teachers can consult universities to develop materials to catch up with the development of the world. Some universities arenow open to clinical consultation in teaching.

In terms of guaranteeing the quality of the teachers, the government pans to conduct a certification. This is not for the sake of the teachers' wealth. The graduate of the certification program will be expected to have four competencies, pedagogical, individual, professional, and social. With those competencies, teachers will be better in the way they teach and in turn, the will get better salary as the consequence for the teacher.

\section{Output and outcome of an Education Process}

Graduates are the product of an education institution. The output of an education process is said to be successful if the graduates can get high scores. High scores indicate that the student is high performers and reflects the success of the éducation institution. That's why education institutions' work hard to improve' the learning quality so that they will yield highachiever graduates. They provide supporting facilities to ease the students' understanding so that they achieve high result.

Education output is not only determined by learning procéss but good input will also tailor the process, which'then will influence the quality of the output. Education' institutions compete to get high-qualified input Many strategies of student admission are taken. Moreover, students may enroll in the institútion before their graduation.

Education institution should not only think about the output but it has also to consider the outcome. Attention should be paid to the fact whether the graduates are absorbed in the work or not. If they work, they have to perform well so that the user will consider the alumni of the education institution. If the alumni perform well in the work; their junior will find it easier to get a job too. Good education institutions produce good output and good outçome as well.

$\therefore \quad$ There are some indicators saying that the outcome is not good. They are the difficulty the graduates face in getting a job and when they, are at work, their working performance is not. satisfying. Hence, education institutions as the agent of education should provide the graduates with skills so that they can meet the demand of the user. They have to take quality assurance in education into accoint and the standards of the graduate quality.

$\therefore$ Quality assurance in education shows the performance of certain education institutions. Good education institution will assure their quality to yield both good output and good outcome. Quality assurance in education is a means to, achieve standard of quality in education. High standard is certainly matched with the quality the users expect If the graduate can match their skilis with the demand of the users, they will not find difficulties in getting a job. The job they get: will bring them in a wealthy life, whether they work as an employee or an employer. The consequence is that education institutions which cannot yield graduated who can meet the users' standard or establish a work by themselves will shape unemployed. As a result, we will always get behind and poor. 


\section{Conclusion}

Education provides students with knowledge, skills, and life value. A person will be able to work well with his knowledge and skills owned. To get the skills and knowledge, he needs to attend education, which needs a long time. The result of education can be achieved in around. 15 to 20 years ahead. The success of an education process will bring the graduates to a better future for the graduates and better future for the nation as general.

Improvement and consideration in education should be improved: To better the education process we need to synergize the components of education and the environment. To yield a better result, high amount of fund is needed. The government is" responsible to allocate a certain amount of budget to meet education need. Besides, the government needs to improve the quality of the education process. What needs improving is not only the process in the class but also the agents executing the education process. The process of improvement should be long life. The final remark is that schooling is limited in time but learning is long life.

\section{Bibliography}

Department of National Education. (2002): Manajemen peningkatan mutu berbasis sekolàh : it, s(kónsep dasar). Jakarta.

Department of National Education. (2003). Undang-undang Republik Indonesia Nomor 20 , . . Tahun 2003 tentang sistem pendidikan nasional. Jakarta: bureau of Law and Organization General Secretariat Department of National Education.

Hasdullah. (2006). Dasar-dasar pendidikan. Jakarta: Rajagrafindo persada.

Knight, G.R. (1982). Issues and alternatives in educational.philosophy' Michigan: Andrews , University press.

Slamet 'ُ.H. (2000). Karakteristik kepala sekolah tangguh. ' Jumal pendidikan, dan Kebudayaan 025.319-332.

Sưyanto.,(2007). Tantangan Profesional guru di era global. Yogyakarta: UNY 